\title{
A perspective on multinational enterprise's national identity dilemma
}

\author{
Surender Munjal, PhD \\ Associate Professor, James E. Lynch India and South Asia Business Centre, \\ Leeds University Business School, \\ University of Leeds, UK
}

Pawan Budhwar, PhD

Professor of International HRM,

Aston Business School,

Aston University, UK

\section{Vijay Pereira, PhD}

Associate Professor and Dean (Research), Faculty of Business,

University of Wollongong in Dubai, UAE 


\title{
A perspective on multinational enterprise's national identity dilemmas
}

\begin{abstract}
This conceptual paper identifies gaps and contributes to the literature on 'identity' dilemmas faced by multinational enterprises operating in a globalised world. Various characteristics and business strategies of multinational enterprises are delineated and analysed through the lens of social identity theory and international business concepts such as market and institutional logic. Our analysis, based on multiple cases, and derived from a variety of industries and countries, associates the identity dilemma to informed business strategy. Our findings suggest that while multinational enterprises face identity dilemmas that they sometimes use to their advantage, it also poses several challenges. Through our conceptualisation, we derive five distinct propositions to shape future research directions.
\end{abstract}

Keywords: Identity, multinational enterprises, globalisation, value chain, tax planning, transfer pricing, technology. 


\section{Introduction}

An important and contemporary change driven by the phenomenon of globalisation is the rapidly growing ‘borderless’ world wherein multinational enterprises (MNEs) are increasingly becoming 'stateless' (Jones, 2006). MNEs are progressively spreading their key functions, such as production, innovation and distribution activities across national borders (Buckley 2011), embedding in multiple locations with the aim to exploit location advantages (Buckley \& Munjal, 2017; Meyer, Mudambi, \& Narula, 2011; Mitsuhashi \& Min, 2016). While, on the one hand, this leads to integration of firms (Mathews, 2006; Munjal, Buckley, Enderwick, \& Forsans, 2013; Thite, Wilkinson, Budhwar, \& Mathews, 2015) spread across the globe, thus forming global value chains (Gereffi \& Fernandez-Stark, 2016; Mudambi, 2012; UNCTAD, 2015; Zeng \& Glaister, 2016), and on the other hand, this is culminating into a divorce like situation where MNEs lose or shed their national identity and at times even disguise it to their advantage.

Although, this has obvious advantages (see Giddens, 2002 for a detailed discussion on advantages of globalisation), it poses inevitable challenges to nation states. Exploiting the advantages of globalisation, many MNEs have outgrown and have increasingly challenged the power of nation-states (Chandler \& Mazlish, 2005; Kuehnl, Furst, Homburg \& Staritz, 2017). Recently, the UK's parliamentary committee on public account grilled MNEs such as Amazon, Google and Starbucks for cases of not contributing enough to the exchequer. There were widespread allegations that these MNEs were avoiding tax by putting forward their national identity to be Irish. Such practices have larger political implications, as for example, the recent de-globalisation move in the form of Brexit and the election of Donald Trump as the president of the USA.

Indeed, the phenomenon of 'stateless' MNEs and 'borderless' world is driven by the capitalist agenda where MNEs seek to build worth both within their hierarchy (hierarchical capitalism) and outside with local partners (alliance capitalism). While, these aspects are well noted by Dunning (1997) in his seminal work - Alliance Capitalism and Global Business, there is a lack of parallel scrutiny on the national identity of MNEs. We thus argue that this novel dimension on multiple national identities warrants theoretical analysis to explore the nexus between the MNEs' international business strategy and national identity and build a comprehensive 
understanding on this subject that is necessary for the better governance of businesses in our societies.

In order to extend the literature in this area, we start by revisiting and revising the definition of the multinational enterprise. It is important that the definition should also continue to evolve with the changing nature and characteristic of modern day MNEs as the reasons for their creation, existence, survival and growth might be different to multinational enterprises, which operated about quarter of a century ago. We use the time period around 1990 as a cut-off point when the USSR disintegrated to create commonwealth states, when many emerging markets liberalised their economic policies which then enabled the further growth of the emerging markets MNEs, etc. For the purpose of this special issue, we define multinational enterprise as an enterprise that holds multiple national identities consequent to owning, controlling and coordinating activities across national borders. Our definition is a natural extension of the primary definition by Buckley and Casson (1976) in their seminal work - 'The Future of Multinational Enterprise' which states that a multinational enterprise is an enterprise which owns and control activities in different economies (p. 1). Our definition emphasises on the multiple national identities perspective that MNEs in the present globalised world may hold or are pursuing as a result of their multinational business operations.

In this respect it is worth noting that unlike individual human beings, their country of origin does not restrict the MNEs' identification. Even though, the MNE's national identity can be associated with the place where its head office (also known as headquarter- HQ) and corporate office are located, i.e., the address registered as the official place for communication, MNEs can change their national identity, from one country to another country by taking some formal steps prescribed in the law (e.g., Conroy, Collings \& Clancy, 2017). In fact, MNEs may have more than one head office, for e.g., the European Aeronautic Defence and Space Company has two head offices, one in Paris and the other in Munich. Similarly, Rio Tinto, the mining and metal giant corporation, has two head offices one in London and the other in Melbourne. Another example is that of Royal Dutch Shell and Unilever, who both maintain their binational identities. On the contrary, some multinationals do not have any head office. For instance, Accenture, a global consulting multinational enterprise does not have any head office (Dvorak, 2007). 
In a nutshell, a multinational system allows flexibility in portraying a national identity to an enterprise. Besides, even though they operate within an array of national contexts, the complexity of the MNEs' national identity further intensifies when it comes to the nationality of its shareholders and the nationality of its leadership.

It is in this complex and contextual setting that this article explores various international business strategies to highlight how MNEs confront its identity dilemma, either by revealing or concealing its original or acquired national identity, especially as it suits their (economic) interests. We utilise the social identity theory along with the market and institutional logics as theoretical lenses for our analysis. Social identity theory provides different facets on identity while market and institutional logics provide the economic rationale of MNEs and the influence of institutional contexts wherein they operate.

\section{Social Identity Theory and Market and Institutional Logics}

The concept of identify has been recognised as a critical construct in social psychology as it tends to emphasise the importance of the 'self' which directs a person's (individuals or organizations) actions (Stets \& Burke, 2000). Scholars argue that the self is reflexive and hence it enables persons (individuals and organisations) to classify themselves to a given social category. Through this process of classification, an identity (or identification) is formed. The social categories (or social categorisation) cover many types of social classifications that can identify members of society based on characteristics such as religion, gender, nationality, social status, and membership of an organisation (Tajfel \& Turner, 2004). Identity ultimately helps individuals to cognitively segment the social milieu and then locate or define oneself

within it. For example, a person may define himself as 'I am a Christian'; I am a Canadian’; 'I am a researcher', etc. In this context, and as an example, a recent study by Laleman, Pereira and Malik (2015) analysed data from the Indian information technology (IT) industry, where they identified 10 cultural singularities. These singularities enrich and broaden the existing understanding of cultural value dimensions by incorporating cultural and business singularities that typify 'Indianness'. The concept and 'identity' of 'Indianness', they argue, is an attribute of being an 'Indian' or of Indian culture and is manifested through various cultural, linguistic and social behaviours. Other studies have also researched into 'culture in Indian organisations' 
that clearly identify the indigenous characteristics that categories MNEs (Pereira and Malik, 2015a; Malik and Pereira, 2016).

Scholars (see Ashforth \& Mael, 1989 for details) have applied the social identity theory to organisational studies because the issues and resolutions associated with identification applies to organisations as much as to individuals. For instance, religious identity, social status and membership of an association apply to organisations as much as to individuals. For example, Grace Baptist Mission is a UK based Christian organisation that aims at supporting, helping and caring for Grace Baptist missionaries worldwide.

Ashforth and Mael (1989) argue that organisational identification is a 'specific form' of social identification of the organisation (p.22). The identification problem starts from the organisation's inception and it is influenced by the organisation's existential motives. Enterprises formed for social purposes (popularly known as social enterprises), such as Grameen Bank - a Bangladeshi entity, wants to be identified as fair, socially responsive organisation that exists for the social welfare. On the other hand, enterprises formed for commercial gains, such as the Japanese electronics giant Sony Corporation likes to be seen as an innovative market-leading organisation. Within the retail sector in the UK, Asda (part of the US MNE Walmart) identifies itself to 'low costs', whereas the Co-op relates to 'fair trade'.

The social identification of organisations becomes more intriguing in the context of multinational enterprises. This is partly because national identity adds an extra degree of layer to organisational identification and it is partly because MNEs meddle with their national identity as a part of their international/global business strategy. We thus argue that to unbundle and understand the international/global business strategies we need to weave in institutional logic and market logic in the social identity theory, because MNEs operate in various institutional milieus, which govern their economic behaviour.

Institutional logics provide the common rules that govern organisational action in a given institutional environment (Hughes, Powell, Chung \& Mellahi, 2017; Kasper \& Streit, 1998; Nicolini, Delmestri, Goodrick, Reay, Lindberg \& Adolfsson, 2016; Thornton 2004). Greenwood, Díaz, Li, and Lorente (2010, p. 521) argue that “organizational forms and managerial practices are manifestations of, and legitimated by, institutional logics”. This suggests that MNEs take 
decisions within the given parameters, which then affect their social identification and status in the society. However, institutions too have implications when it comes to the national identity of an MNE. The extant literature on institutional economics suggests that MNEs are incentivised by nation states in the process of attracting investment (Balasubramanyam, Salisu, \& Sapsford, 1996; Zee, Stotsky, \& Ley, 2002). In contrast, MNEs also choose to avoid and escape from certain locations in order to avoid institutional constraints (Witt \& Lewin, 2007).

Alongside institutional logic, we also utilise market logic in this paper. Market logic means the organisational common sense to successfully operate in given markets wherein MNEs along with other actors (for instance, buyers and suppliers), seek to maximise their performance (e.g., Mitsuhashi, \& Min, 2016). This primarily includes the principles of transaction cost economics (TCE) (Coase, 1937; Williamson, 1981) and the resource based view (RBV) (Barney, 1991, 1996). TCE advocates comparing internal costs of organisation (cost in hierarchy) with the cost of getting operations completed in market that is outsourcing to third parties. In an international business context this means the decision to internalise or outsource to foreign location (Buckley \& Casson, 1976; Dunning, 1977, 1988, 1993).

In parallel, to a MNE's decision to minimise costs of operations, the MNE also seeks to strengthen its competitive advantages so that it is successful against competitors (Hymer, 1976) and is also successful when it comes to negotiating with supply chain partners (Hobbs, 1996). This motivation to enhance competitive advantage is also associated with the location choice of the MNE. The extant literature in the international business field, suggests that MNEs invest in certain location in search of strategic assets, such as advanced technological assets, marketing assets, and human resources that can build its competitive advantages (Buckley, Forsans, \& Munjal, 2012; Pereira and Malik, 2015b).

Thus, we argue that an MNE's national identification is determined by the choices and decisions taken by them to operate, enter, invest, divest etc., and these are driven by economic, resource and locational advantages. We depict this complex relationship through figure 1. 
Figure 1: The Complex Relationship of Social Identity and Market and Institutional Logics Leading to MNEs National Identity Dilemma

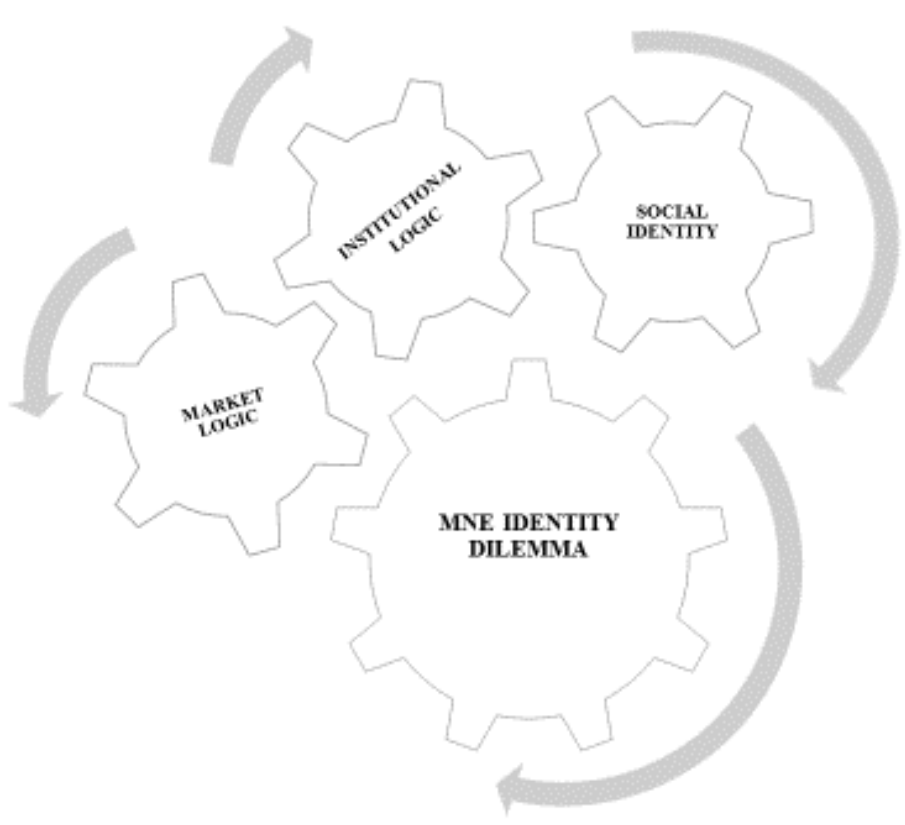

Source: Authors’ compilation

\section{Market Logic and National Identity of Multinational Enterprises}

\subsection{Country Specific Advantages}

Under this heading, our first argument relates to competitive advantages, arising from the MNE's country of origin. Competitive advantages refer to knowledge, skills, abilities and other attributes (KSAOs) that enables multinational enterprises to outperform its competitors (Hymer, 1976). Literature on competitive advantages has its origin in the theories of classical economics, notably 'The Wealth of Nation' by Adam Smith and 'Comparative Advantages Theory’ by David Ricardo. These seminal works primarily suggest that the skewed distribution of labour and unequal endowment of natural resources across different countries creates 
national advantages. This advantage makes firms in a particular country more specialised and efficient than their counter parts in other countries. A good example of this argument is that of the US technology giants Microsoft and Apple. Consumers over the world are overly dependent on software by both these monopolistic firms when it comes to day-to-day use of technology, as they hold the majority of the market share between themselves. Both these US MNEs have global manufacturing and $R \& D$ centres based on the principle of comparative advantage. The Apple iPod example (Dedrick, Kraemer, \& Linden, 2009), depicts how the US\$ 144 (Chinese) factory price of an iPod was less than ten per cent in terms of contribution to Chinese value-added, as the bulk of the components (about US\$ 100) are imported from Japan and much of the rest coming from the United States and the Republic of Korea. Hence here both Apple and Microsoft are examples of MNEs who have skewed distribution of labour and unequal endowment of natural resources across different countries, which creates for them national advantages, of being US based MNEs (as suggested by Smith and Ricardo).

Strategically, Porter (2000) extended this idea in the form of the diamond model. He argues that firms achieve competitive advantages not just from national factors or conditions but also from demand conditions, which are related to supporting industries and a firm's own strategy, structure and rivalry. Nevertheless, MNEs' competitive advantages are created and sustained through a highly localised process associated with its home country as Porter claims that "national value, culture, economic structures, institutions, and histories all contribute to competitive success" of the firm (p. 74).

These fundamental arguments are thus synthesised by scholars in the field of International Business. For example, Rugman (1981) formed a CSA/FSA (country and firm specific advantages) typology. Rugman suggests competitive advantages arise because of CSAs when for instance, business friendly institutions and availability of natural resources exist; while, competitive advantages arise because of FSAs when for instance, the firm's ability to create globally known brand and advanced cutting edge technology exist.

Recent research (e.g., Buckley, Munjal, Enderwick, \& Forsans, 2016) in this area argue that CSAs often form the basis of FSAs indicating that there is a strong relation between firm specific and country specific advantages. In fact, the firms often 'bundles' its firm specific advantages with country specific advantages while exploiting them in the market (Hennart, 
2009). Thus, the country of origin (as part of its identity) has a strong influence on the firm's competitive advantage.

There are thus several examples, which suggest that the MNE's country of origin indicates its specialisation and therefore MNEs portray their national identity to indicate its competitive advantages in a particular industry. For instance, engineering and automobile MNEs based in Germany (such as Bosh and Volkswagen), often promote their national identity as an indicator of their precision and quality products. A similar argument applies to robotics and consumer electronics goods producing multinational enterprises, such as Sony and Samsung, from Japan and Korea respectively. Examples from other industries include- Information technology firms, such as Tata Consulting Services and Infosys from India; firms in fashion industry, such as the FCUK and L'Oréal from France and Versace, Prada and Armani from Italy, take pride in their national identification. Thus, these firms market themselves through such brand expertise and quality, which are 'identified' by consumers and customers as a product or service of a particular home country.

Nonetheless, the country of origin may also have a negative influence on the firm's competitive advantages. Generally speaking, a case of a developing country firm could fall into this category (Hobbs, 1996). As a response, affected firms seek to renounce their national identity in order to overcome the negative perception associated with such an identity. Our arguments are in line with the 'identity based view of foreignness' (for more details see, Edman, 2016). A recent and relevant example here could be the 9.99\% stake (GBP 1.1 billion) of Qatar Airways, the biggest shareholder in British Airways and Iberia (Spanish Airlines) (The Telegraph, 2015). Its overall owner, International Consolidated Airlines Group (IAG) is in the process of acquiring Ireland's Aer Lingus, which would mean largest ownership again by Qatar Airways. However, each national carrier i.e. British, Spanish and possibly Irish will maintain their individual national identities for reasons argued above. We therefore argue that:

Proposition 1: Opportunity to gain national competitive advantages from host countries adds to multiplicity of national identity.

\subsection{Global Value Chains}


Our second stream of argument emerges from the MNEs creation of and participation in global value chains (GVCs). This follows our previous proposition that national comparative advantages are seen as fundamental location advantages by MNEs in the creation of a global value chain. Gereffi, Humphrey, and Kaplinsky (2001) suggest that MNEs are principal agents responsible for making valuable chains global. This idea emphasises internal reorganisation of production so that economic activities can take place at different locations across the globe where it can be best performed (Buckley \& Strange, 2015). As earlier discussed, different countries specialise in different aspect of production or creation and supply of services, which could be due to the skewed distribution of labour and unequal endowment of natural resources. For instance, China has become the world's production centre due to a lower wage rate, California (USA) is known as the hub for high technology intensive firms, and countries in South Asia - Bangladesh, Pakistan, India and Sri Lanka are considered the world's hub for textile production.

To a large extent national and regional governments and supranational organisations, such as the World Bank (WB), the World Trade Organisation (WTO) and the International Monetary Fund (IMF), help multinational enterprises in reallocation of production across borders. The Organisation of Economic Cooperation and Development (OECD) notes that "the past decades have witnessed a strong trend towards the international dispersion of value chain activities such as design, production, marketing, distribution, etc.” (OECD, 2016, p.1). Notable examples that the OECD report is referring to are firms quoted by Oxfam (2004), such as the Hong Kong-based Li \& Fung and Taiwanese-based Nien Hsing Textile Company. These firms are at the centre of subcontracting networks which span much of South and East Asia, where they operate by sourcing materials from one place, dyes from another, zips from somewhere else and assembling the outfits in yet another location (Oxfam, 2004). According to Oxfam, these Hong Kong and Taiwanese companies source their design and purchase orders from branded MNEs based in Europe and America; undertake manufacturing, instructions, managerial and commercial control from China, India, Korea, Vietnam and Thailand; and finally finished goods are then sent off to Europe and the US markets.

Scholars (e.g., Buckley \& Ghauri, 2004; Buckley \& Hashai, 2004) suggest that MNEs are perfectly placed to exploit advantages from multiple locations. They engage in global 
expansion of its value chain as it allows them to exploit location advantages and enhance their competitive advantage by sourcing globally (Cassiman \& Golovko, 2011). For instance, the value chain of Apple, the famous US technology giant, ranges from sourcing of aluminium from mud pits in Indonesia, manufacturing and assembly of components in China, while the designing and technology is handled back home in California.

Linking the above discussion to our arguments, we contend that within this process of globalisation, often the MNE spread their operations across many countries and it becomes difficult to identify it with or to any one country as its base. We argue that, in such a situation, it is conceptually wrong to say that the a MNE belongs to a particular country. Multiple bases strengthen the firm's competitive advantages but weakens it country identification. For example, Lakshmi Mittal the chairman and CEO of the Arcelor Mittal group, has been on record saying that his steel empire (the world's largest manufacturer of steel) is a global brand and identity, when asked if his group was Indian. Mr Mittal holds an Indian passport, is a permanent resident in London, and his group is headquartered in Luxemburg.

While the influence of country of origin on competitive advantages is quite evident, it is striking to know how MNEs have become truly transnational. The United Nations Conference on Trade and Development (UNCTAD) prepares a transnationality index (TNI) which is an average of firm's foreign assets to total assets, foreign sales to total sales and foreign employment to total employment. Table 1 shows the top 20 firms across the world, ranked according to their TNI. The table shows that these multinational enterprises are surprisingly diverse, as they operate in multiple industries and countries. A majority of their assets, sales and employment are outside their home country and in many cases 100 percent assets, sales or employment are abroad.

Table 1: Top 20 Multinational Enterprises

\begin{tabular}{|l|l|l|l|l|l|l|l|}
\hline TNI & \multicolumn{1}{|c|}{ Corporation } & Home economy & \multicolumn{1}{|c|}{ Industry } & Assets & Sales & $\begin{array}{c}\text { Employ } \\
\text { ment }\end{array}$ & $\begin{array}{c}\text { TNI } \\
\text { (Per cent) }\end{array}$ \\
\hline 1 & Nestlé SA & Switzerland & $\begin{array}{l}\text { Food, beverages and } \\
\text { tobacco }\end{array}$ & 96 & 98 & 97 & 97.1 \\
\hline 2 & $\begin{array}{l}\text { Anglo American } \\
\text { plc }\end{array}$ & United Kingdom & Mining \& quarrying & 95 & 93 & 94 & 94.2 \\
\hline 3 & Xstrata PLC & Switzerland & Mining \& quarrying & 96 & 90 & 95 & 93.7 \\
\hline 4 & $\begin{array}{l}\text { Anheuser-Busch } \\
\text { InBev NV }\end{array}$ & Belgium & $\begin{array}{l}\text { Food, beverages and } \\
\text { tobacco }\end{array}$ & 95 & 91 & 93 & 92.8 \\
\hline
\end{tabular}




\begin{tabular}{|c|c|c|c|c|c|c|c|}
\hline 5 & ABB Ltd. & Switzerland & Engineering services & 83 & 98 & 95 & 91.9 \\
\hline 6 & ArcelorMittal & Luxembourg & $\begin{array}{l}\text { Metal and metal } \\
\text { products }\end{array}$ & 98 & 100 & 76 & 91.1 \\
\hline 7 & Linde AG & Germany & Chemicals & 95 & 92 & 85 & 90.7 \\
\hline 8 & $\begin{array}{l}\text { Vodafone Group } \\
\text { Plc }\end{array}$ & United Kingdom & Telecommunications & 92 & 88 & 91 & 90.4 \\
\hline 9 & $\begin{array}{l}\text { Schneider Electric } \\
\text { SA }\end{array}$ & France & $\begin{array}{l}\text { Electricity, gas and } \\
\text { water }\end{array}$ & 91 & 92 & 87 & 90.1 \\
\hline 10 & WPP PLC & United Kingdom & Business services & 87 & 88 & 90 & 88.1 \\
\hline 11 & $\begin{array}{l}\text { Koninklijke } \\
\text { Philips Electronics } \\
\text { NV }\end{array}$ & Netherlands & $\begin{array}{l}\text { Electrical \& electronic } \\
\text { equipment }\end{array}$ & 94 & 97 & 73 & 88.0 \\
\hline 12 & $\begin{array}{ll}\text { Barrick } & \text { Gold } \\
\text { Corporation } & \\
\end{array}$ & Canada & Gold mining & 96 & 97 & 71 & 87.9 \\
\hline 13 & SABMiller PLC & United Kingdom & $\begin{array}{l}\text { Food, beverages and } \\
\text { tobacco }\end{array}$ & 99 & 83 & 80 & 87.6 \\
\hline 14 & AstraZeneca PLC & United Kingdom & Pharmaceuticals & 77 & 98 & 87 & 87.2 \\
\hline 15 & Pernod-Ricard SA & France & $\begin{array}{l}\text { Food, beverages and } \\
\text { tobacco }\end{array}$ & 85 & 91 & 85 & 87.1 \\
\hline 16 & Unilever PLC & United Kingdom & Diversified & 89 & 92 & 80 & 87.1 \\
\hline 17 & Liberty Global Inc & United States & Telecommunications & 100 & 99 & 59 & 85.8 \\
\hline 18 & $\begin{array}{l}\text { Teva } \\
\text { Pharmaceuti-cal } \\
\text { Ind Ltd }\end{array}$ & Israel & Pharmaceuticals & 74 & 97 & 84 & 84.9 \\
\hline 19 & BG Group plc & United Kingdom & $\begin{array}{l}\begin{array}{l}\text { Electricity, gas and } \\
\text { water }\end{array} \\
\end{array}$ & 88 & 84 & 82 & 84.7 \\
\hline 20 & $\begin{array}{l}\text { Hon Hai Precision } \\
\text { Industries }\end{array}$ & $\begin{array}{l}\text { Taiwan Province } \\
\text { of China }\end{array}$ & $\begin{array}{l}\text { Electrical \& electronic } \\
\text { equipment }\end{array}$ & 93 & 97 & 63 & 84.3 \\
\hline
\end{tabular}

Source: UNCTAD (2016)

Thus, we contend that this diversity essentially adds to their identity dilemma. To make our point, we cite the following examples. For example, Liberty Global, although a US firm, all its assets are based abroad and 99 percent of its revenues come from outside the USA. As discussed above, the useful example of ArcelorMittal, a steel and metal producing giant is relevant here. Since the firm is headquartered in Luxembourg, and its owners and senior management are based and are permanent residents in London, can we really say this firm is an Indian firm or a UK firm? Or, is it Luxembourg because its head office is based there? However, to say that ArcelorMittal is a Luxembourg firm is also debateable because all its sales come from abroad. Another example, that of Standard Chartered Bank, a British banking and financial MNE, which opened its office in UK in 1853 and is still headquartered there, is also very relevant to our arguments here. Despite its UK roots and base, Standard Chartered Bank does not portray its UK identity. In fact, it does not conduct retail banking in the UK. The bank gets around $90 \%$ of its profits from Asia, Africa and Middle East. Standard Chartered 
has more than 1200 branches across 70 countries, other than the UK. Based on our arguments above we propose that:

Proposition 2: The MNE's engagement in global value chain adds to multiplicity of national identity.

\subsection{Market Servicing Strategy}

Our third argument draws from the extant literature on international marketing, where we contend that the MNE adapts to local market conditions as a way to maximise its economic gain and social acceptance, leading to an identity. Prior research suggests that products are usually adapted to accommodate for the local taste and preferences (Craig \& Douglas, 2005); local pricing reflects the legal tender and purchasing power of the host market (Alford \& Biswas, 2002); labelling and packaging follows local standards prescribed by local government agencies; and most importantly, local advertising and localised promotion increases customer appeal (Ashforth \& Mael, 1989; Gereffi et al., 2001; Mallick \& Marques, 2017).

For reaping these benefits of adaptation, MNEs follow multi-domestic strategies (Bartlett \& Ghoshal, 1989) where many subsidiaries serve different markets in their own local ways. MNEs allow space for the subsidiary's entrepreneurship and generation of subsidiary specific competitive advantages (Rugman, Verbeke, \& Yuan, 2011). Thus, subsidiaries gain more independence and autonomy when it comes to conducting business in local markets. In other words, subsidiaries embed in the local contexts and are generally seen as a local firm (Meyer et al., 2011; Pereira, Munjal, \& Nandakumar, 2016).

Further example of our arguments above is that of SKII, a premium range of skin care products which was developed by a Japanese subsidiary of Procter and Gamble (P\&G). The product is very popular and associates itself with the Japanese culture so much so that very often it lends a distinct Japanese identification to P\&G. Another example is that of Unilever, an Anglo-Dutch multinational enterprise, which has several subsidiaries and are seen as local firms in many countries. The local identification also arises because the subsidiary name often includes the country where it operates giving an initial impression that it is a local firm. For instance, in India, Unilever is known as Hindustan Unilever and in Indonesia it is known as Unilever Indonesia. In fact, global brands such as Colgate, Coca-Cola and Xerox have become so 
synonym with local emerging market customers (such as those in South Asia), that these names have replaced the original words of toothpaste, cold drink and photocopying respectively. Coca-Cola has even gone to the extent of advertising that "if it is a cold drink it has to be a Coca-Cola”.

In addition to the localisation, the virtualisation of businesses due to advances in the use of Internet and related technologies is yet another factor that adds to national identity dilemma of MNEs. Our argument here is that virtualisation of business disallows the firm to be identified as a national firm. There are two reasons for this contention: first, the MNE predominating internet usage as its mode of doing business is seen as a global firm rather than a firm belonging to a particular nation; second, the MNE may not have any physical location as the firm resides virtually (on the internet). Firms engaged in e-commerce, such as Amazon, Ebay Alibaba, and Flipcart, are good examples here.

Additionally, it can be argued that there is an extensive literature on born global firms which claims that firms following a 'click' based business model not only spread globally quicker but they can start their business with a 'big-bang' as they physically and virtually operate across the globe at the same time (Knight \& Cavusgil, 2004; Rennie, 1993). Due to the global spread and lack of physical address, these firms are often seen as global firms with their virtual home on the internet. Although in some famous cases such as Amazon (US) and Alibaba (China), the national identity is quite well known but in a majority of e-commerce businesses the national identity is not clearly known. On the basis of above discussion, we propose that:

Proposition 3: Localisation and virtualisation strategy to serve foreign markets leads to the multiplicity of national identity of MNEs.

\section{Institutional Logic and National Identity of Multinational Enterprises}

\subsection{Round Tripping of Investment}

Round tripping of investment is another issue connected with national identity of the MNE (Beugelsdijk, Hennart, Slangen, \& Smeets, 2010). Round tripping means channelling of investment by a resident enterprise back into its home economy via a foreign country (Xiao, 2004). Figure 2 shows how an enterprise ' $X$ ' invests some funds in its home country, but the investment comes through an enterprise ' $\mathrm{X}$ *' from a foreign country. Enterprise $\mathrm{X}^{*}$ is actually 
a special purpose enterprise which is formed for the purpose of reflecting investment back into the home country.

Figure 2: Round Tripping of Investment

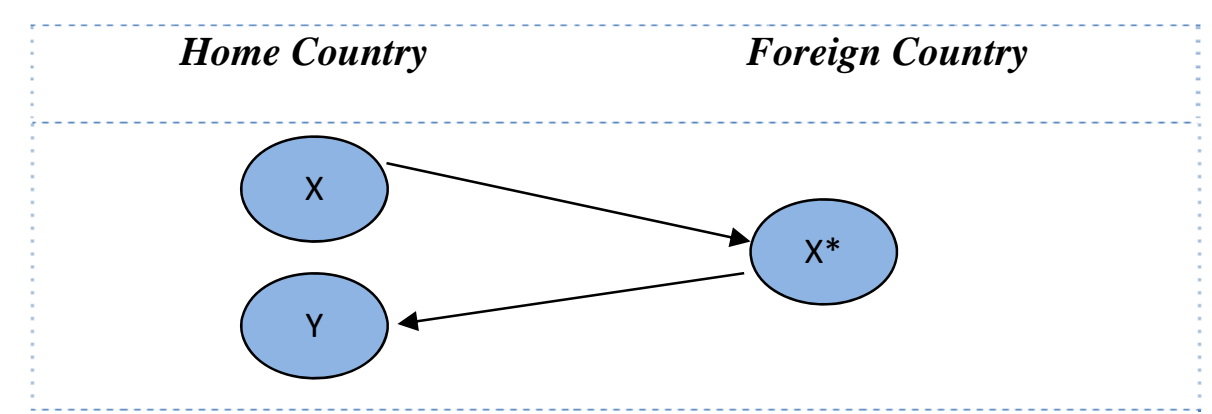

Source: Authors' compilation

This round tripping is usually done for obtaining investment incentives available to foreign investors but not domestic ones. Hanlon, Maydew, and Thornock (2015) found that many US firms route their funds for investment into the US capital market through phony foreign identities "making it appear that the investments are coming from true foreign investors" (p. 257). This allows the investors to evade most tax on the investment income because the US tax laws favourably treats foreign investors in the US securities than domestic investors. Thus, the enterprise disguises its true national identity in order to gain the investment incentives available for foreign investors.

There are many more examples of round tripping of investment in the world. For example, Indian multinational enterprises use Mauritius as their home base (Sethi, 2009; Srivastava, 2003), while Chinese firm often uses Hong Kong, Singapore and Taiwan as their base (Broadman \& Sun, 1997; Fung, Yau, \& Zhang, 2011).

Theoretically, this behaviour of the firm is explained as institutional arbitrage to exploit market imperfections (Fung et al., 2011). This is because MNEs have the unique ability to exploit local policies and conditions (Buckley \& Ghauri, 2004; Buckley \& Hashai, 2004) by creating a cross-border arbitrage around institutions offered in different countries (Kogut, 1983). However, in effect, it is a case of disguising true national identity by acquiring a phony identity of a foreign country. Based on our above discussion we argue that: 
Proposition 4: Round tripping of investment adds to the multiplicity of national identity of MNES.

\subsection{Tax Avoidance}

Similar to the concept of round tripping above, MNEs also resort to various types of arbitrage in order to increase profitability and circumvent market impediments (Eden, 2009; Shapiro, 2006). An important arbitrage that relates to national identity is taxation. Research suggests that MNEs are sensitive to taxation (Altshuler, Grubert, \& Newlon, 2001) and in order to avoid tax liability and profit shifting these firms very often fudge their national identity.

There is an established literature in the international business field on transfer pricing which addresses the MNEs' motives and strategies of tax avoidance (for details see Feinschreiber, 2004). Research in this area illustrates how MNEs transfer their profits from high tax countries to low tax countries as a way to minimise their tax liabilities (Contractor, 2016; Grubert \& Mutti, 2001; Rego, 2003). Primarily, MNEs establish their offshore offices in tax havens where the tax liabilities are minimal (Desai, Foley, \& Hines, 2006; Hanlon et al., 2015).

A recent study by Jones and Temouri (2016) examine the factors that lead MNEs to set up tax haven subsidiaries. Their work is novel in offering evidence for a large panel of firms across twelve developed countries. They find that the variety of capitalism of a MNE's home location has a strong effect on the likelihood of setting up tax haven subsidiaries. Another important finding is that the home country corporate tax rate has a minimal impact, which they argue suggests that corporate tax liberalisation is unlikely to dissuade MNEs from undertaking tax haven activity. Last, but not least, they find a positive correlation between MNE's level of technological intensity, measured in terms of intangible assets, and the likelihood of setting up tax haven subsidiaries.

It is this last finding which Jones and Temouri (2016) use to shed light on the general tax structure, which is used to benefit from tax havens. Consider the scenario where a parent company has two overseas subsidiaries, one of which is located in a tax haven. The parent firm has in the past created intellectual property in its home location, which is essentially its firmspecific advantage. However, for tax purposes, this intellectual property (IP) is registered to the tax haven subsidiary in a tax haven location, such as the Cayman Islands or the Bahamas, 
where the levels of corporate income tax are zero or close to it. This can be considered the "first" avoidance of tax, which is forgone in the home country, where the IP was created with the help of the firm's capabilities but also the surrounding home country advantages.

But this goes even further, where the IP, which is now registered in the tax haven subsidiary is used by other subsidiaries located in other host countries that are not tax haven locations. However, the use of the IP comes at a high price, allowing the parent firm to avoid corporate tax in the other host location by declaring lower profits due to higher costs. Put simply, the use of IP with manipulated prices will show up in the balance sheet of the host country subsidiary as squeezing their profits, which means that they are liable for lower tax payments to the host country government. This is another way the parent MNE avoids tax, which is now forgone by the other host country government. Therefore, not only is the MNE able to avoid taxation at home but also it is also able to minimise taxation in foreign locations, through the use of tax havens.

Kleinbard (2011) designates the income escaping tax as 'stateless income’ because this income loses its motherhood state, i.e. where it is actually earned? Is it the location of the customers or the factors of production? Contrary to the 'stateless income' doctrine we argue that the income is not stateless as such because it finally rests in some tax heaven state. For instance an illustration by Kleinbard (2011, p. 703) highlights that "a U.S. firm that sells software in Germany earns stateless income when the added value from the sales to German consumers is taxed in Ireland rather than Germany. The same analysis would apply to a German firm whose income from sales to U.S. or French customers come to rest for tax purposes in Luxembourg.”

Thus, in effect, the strategy of tax avoidance by transferring income effectively leads into addition of their national identities, which the multinational enterprises often claim to be their main location of control. For instance, ArcelorMittal claims that it is a Luxembourg firm however all its production and its sales are outside Luxembourg. There are several other examples where MNEs have avoided tax liability by adding fake national identities (Dharmapala \& Riedel, 2013). Therefore, we argue that:

Proposition 5: The strategy of tax avoidance adds to the MNE's national identity. 


\section{Conclusions}

Based on arguments and examples cited above, where we come up with five propositions on the dilemma of MNE identities, we conclude that the social identification of MNEs is catching scholarly attention, and we attempt to contribute to this debate. This is partly because national identity adds an extra degree of layer to organisational identification and partly because MNEs meddle with their national identity as a part of their international/global business strategy. More specifically, this paper contributes to this special issue in the backdrop of national identity of MNEs and explores how these organisations intentionally exploit their national identity while forming various strategies when it comes to conducting international business.

Our paper presented a perspective on the national identity dilemma of MNEs through the lenses of social identity theory, market logic and institutional logic. In this paper we utilise social identity theory, which provided a theoretical underpinning for the MNEs identity dilemma and market and institutional logic provide the theoretical rationale behind IB strategies of MNEs. Thus, social identity theory offered a social-psychological perspective (Tajfel \& Turner, 2004) which aided in restoring "some coherence" to the issue of organisational identification (Ashforth \& Mael, 1989, p.20). In terms of a cross-disciplinary perspective study, we claim that by complementing sociological theories with an international business perspective, our study highlighted the strategic motivation that contributes to the identification dilemma. More specifically we do so via our analysis in two major ways: first, we extend social identity theory by bringing its application to the international business field. There has been a significant gap between organisation studies literature and international business, despite various overlaps. We argue that market and institutional logics provide additional foundations to the social identity theory necessary for its application to multinational enterprises. We mainly argue that our analysis bridges this gap and paves way for scholars in both fields to interact (Pereira, 2017). Second, we reveal and analyse the national identity dilemma of MNEs - a critical fact that has been a cause of concern to policy makers. We expect our analysis will assist in the understanding of the issue and provide an aid in finding practical solutions. 


\section{References}

Alford, B. L., \& Biswas, A. 2002. The effects of discount level, price consciousness and sale proneness on consumers' price perception and behavioral intention. Journal of Business Research, 55(9): 775-783.

Altshuler, R., Grubert, H., \& Newlon, T. S. 2001. Has US investment become more sensitive to tax rates? In J. J. R. Hines (Ed.), International taxation and multinational activity: 9-32. Chicago: University of Chicago Press.

Ashforth, B. E., \& Mael, F. 1989. Social identity theory and the organization. Academy of Management Review, 14(1): 20-39.

Balasubramanyam, V. N., Salisu, M., \& Sapsford, D. 1996. Foreign direct investment and growth in EP and its countries. The Economic Journal, 106(434): 92-105.

Barney, J. 1991. Firm resources and sustainable competitive advantage. Journal of Management, 17(1): 99-120.

Barney, J. 1996. The resource-based theory of the firm. Organization Science, 7(5): 469.

Bartlett, C. A., \& Ghoshal, S. 1989. Managing across borders: The transnational solution. London: Harvard Business School Press.

Beugelsdijk, S., Hennart, J.-F., Slangen, A., \& Smeets, R. 2010. Why and how FDI stocks are a biased measure of MNE affiliate activity. Journal of International Business Studies, 41(9): 14441459.

Broadman, H. G., \& Sun, X. 1997. The distribution of foreign direct investment in China. The World Economy, 20(3): 339-361.

Buckley, P., \& Munjal, S. 2017. The role of local context in the cross-border acquisitions by emerging economy multinational enterprises. British Journal of Management, 28(3): 372-389).

Buckley, P. J., \& Casson, M. C. 1976. The future of the multinational enterprise. London: Macmillan

Buckley, P. J., Forsans, N., \& Munjal, S. 2012. Host-home country linkages and host-home country specific advantages as determinants of foreign acquisitions by Indian firms. International Business Review, 21(5): 878-890.

Buckley, P. J., \& Ghauri, P. N. 2004. Globalisation, economic geography and the strategy of multinational enterprises. Journal of International Business Studies, 35(2): 81-98.

Buckley, P. J., \& Hashai, N. 2004. A global system view of firm boundaries. Journal of International Business Studies, 35(1): 33-45.

Buckley, P. J., Munjal, S., Enderwick, P., \& Forsans, N. 2016. Cross-border acquisitions by Indian multinationals: Asset exploitation or asset augmentation? International Business Review, 25(4): 986-996.

Buckley, P. J., \& Strange, R. 2015. The governance of the global factory: Location and control of world economic activity. The Academy of Management Perspectives: amp. 2013.0113. 
Cassiman, B., \& Golovko, E. 2011. Innovation and internationalization through exports. Journal of International Business Studies, 42(1): 56-75.

Chandler, A. D., \& Mazlish, B. 2005. Leviathans: Multinational corporations and the new global history: Cambridge University Press.

Coase, R. H. 1937. The Nature of the Firm. Economica, 4(16): 386-405.

Conroy, K.M., Collings, D.G., \& Clancy, J. 2017. Regional headquarter's dual agency role: Micro-political strategies of alignment and self-interest. British Journal of Management, 28(3): 390-406.

Contractor, F. J. 2016. Tax Avoidance by Multinational Companies: Methods, Policies, and Ethics. AIB Insights, 16(2): 10.

Craig, C. S., \& Douglas, S. P. 2005. International marketing research: JSTOR.

Dedrick, J., Kraemer, K. L., \& Linden, G. 2009. Who profits from innovation in global value chains?: a study of the iPod and notebook PCs. Industrial and Corporate Change: dtp032.

Desai, M. A., Foley, C. F., \& Hines, J. R. 2006. The demand for tax haven operations. Journal of Public Economics, 90(3): 513-531.

Dharmapala, D., \& Riedel, N. 2013. Earnings shocks and tax-motivated income-shifting: Evidence from European multinationals. Journal of Public Economics, 97: 95-107.

Dunning, J. H. 1977. Trade, location of economic activity and the multinational enterprise: A search for an eclectic approach In B. Ohlin, P. O. Hesselborn, \& P. J. Wijkmann (Eds.), The International Allocation of Economic Activity: 395-416. London: McMillan.

Dunning, J. H. 1988. The eclectic paradigm of international production: A restatement and some possible extensions. Journal of International Business Studies, 19(1): 1-31.

Dunning, J. H. 1993. Multinational enterprises and the global economy. Wokingham: Addison Wesley Publishing company.

Dunning, J. H. 1997. Alliance capitalism and global business. London: Routledge.

Dvorak, P. 2007. Why Multiple Headquarters Multiply, Wall Street Journal, 19th November 2007 ed.

Eden, L. 2009. Taxes, transfer pricing and the multinational enterprise. In A. M. Rugman (Ed.), The Oxford handbook of international business, Vol. 2nd Edition. Oxford: Oxford University Press.

Edman, J. 2016. Reconciling the advantages and liabilities of foreignness: Towards an identitybased framework. Journal of International Business Studies, 47(6): 674-694.

Feinschreiber, R. 2004. Transfer pricing methods: An applications guide: John Wiley \& Sons.

Fung, H.-G., Yau, J., \& Zhang, G. 2011. Reported trade figure discrepancy, regulatory arbitrage, and round-tripping: Evidence from the China-Hong Kong trade data. Journal of International Business Studies, 42(1): 152-176.

Gereffi, G., \& Fernandez-Stark, K. 2016. Global value chain analysis: a primer: Center on Globalization, Governance \& Competitiveness, Duke University. 
Gereffi, G., Humphrey, J., \& Kaplinsky, R. 2001. Introduction: Globalisation, value chains and development. IDS bulletin, 32(3): 1-8.

Giddens, A. 2002. Runaway world: How globalisation is reshaping our lives: Profile books.

Greenwood, R., Díaz, A. M., Li, S. X., \& Lorente, J. C. 2010. The multiplicity of institutional logics and the heterogeneity of organizational responses. Organization Science, 21(2): 521-539.

Grubert, H., \& Mutti, J. 2001. Taxing international business income: Dividend exemption versus the current system. Washington, DC: American Enterprise Institute.

Hanlon, M., Maydew, E. L., \& Thornock, J. R. 2015. Taking the long way home: US tax evasion and offshore investments in US equity and debt markets. The Journal of Finance, 70(1): 257287.

Hennart, J.-F. 2009. Down with MNE-centric theories! Market entry and expansion as the bundling of MNE and local assets. Journal of International Business Studies 40(8): 1432-1454.

Hobbs, J. E. 1996. A transaction cost approach to supply chain management. Supply Chain Management: An International Journal, 1(2): 15-27.

Hughes, M., Powell, T.H., Chung, L. \& Mellahi, K. 2017. Institutional and resource-based explanations for subsidiary performance. British Journal of Management, 28(3): 407-424.

Hymer, S. H. 1976. The international operations of national firms: A study of direct foreign investment. Lexington, MA: Lexington Books.

Jones, C., \& Temouri, Y. 2016. The determinants of tax haven FDI. Journal of World Business, 51(2): 237-250.

Jones, G. 2006. Nationality and Multinationals in Historical Perspective. Harvard Business School Working Paper Series, \#06(052): 1-32.

Kasper, W., \& Streit, M. E. 1998. Institutional economics: social order and public policy. New York: Wiley Online Library.

Kleinbard, E. D. 2011. Stateless income. Florida Tax Review, 11(9): 701-705.

Knight, G. A., \& Cavusgil, S. T. 2004. Innovation, organizational capabilities, and the born-global firm. Journal of International Business Studies, 35(2): 124-141.

Kogut, B. 1983. Foreipn Direct Investment as a Sequential Process. In C. P. K. D. Audretsch (Ed.), The multinational corporation in the 1980s 38-56. Cambridge: MIT Press.

Kuehnl, C., Furst, A., Homburg, C., \& Staritz, M. 2017. Toward a differentiated understanding of the valuecreation chain. British Journal of Management, 28(3): 444-463.

Laleman, F., Pereira, V., and Malik, A. 2015. Understanding cultural singularities of "Indianness" in an inter-cultural business setting. Culture and Organization. Vol. 21, No. 5, p. 427-447.

Malik, A., and Pereira, V. 2016. Indian culture and work organisations in transition, Routledge (Taylor and Francis), London.

Mallick, S., \& Marques, H. 2017. Export prices, selection into exporting and market size: Evidence from China and India. International Business Review, forthcoming. 
Mathews, J. A. 2006. Dragon multinationals: New players in 21st century globalization. Asia Pacific Journal of Management, 23(1): 5-27.

Meyer, K. E., Mudambi, R., \& Narula, R. 2011. Multinational enterprises and local contexts: The opportunities and challenges of multiple embeddedness. Journal of Management Studies, 48(2): 235-252.

Mitsuhashi, H., \& Min, J. 2016. Embedded networks and suboptimal resource matching in alliance formations. British Journal of Management, 27(2): 287-303.

Mudambi, R. 2012. Flatness the global disaggregation of value creation, Keynote speach in Academy of International Business, UK and Ireland Chapter. Liverpool.

Munjal, S., Buckley, P. J., Enderwick, P., \& Forsans, N. 2013. The Growth Trajectory of Indian MNEs. In C. Brautaset, \& C. Dent (Eds.), The Great Diversity - Trajectories of Asian Development: 191-205. Wageningen: Netherlands: Wageningen Academic Press.

Nicolini, D., Delmestri, G., Goodrick, E., Reay, T., Lindberg, K., \& Adolfsson, P. 2016. Look what’s back! institutional complexity, reversibility and the knotting of logics. British Journal of Management, 27(2): 228-248.

OECD. 2016. Global Value Chains. Paris: OECD.

Oxfam. 2004. Li \& Fung Limited global subcontracting network. Oxfam International, Oxfam Hong Kong.

Pereira, V., and A. Malik. 2015a. Investigating Cultural Aspects in Indian Organizations Empirical Evidence. Cham: Springer International Publishing Switzerland.

Pereira, V., and Malik, A. 2015b. Human capital in the Indian IT / BPO industry. In: Palgrave Macmillan, London. ISBN 9781137481504.

Pereira, V. 2017 (forthcoming). Journal editors as philosopher kings: The duties and responsibilities of academics in a changing world. Journal of South Asian History and Culture. Volume 8, Issue 3.

Pereira, V., Munjal, S., \& Nandakumar, M. K. 2016. Reverse dependency: a longitudinal case study investigation into Headquarter-Subsidiary relationship in the context of an emerging country. International Studies of Management \& Organization, 46(1): 50-62.

Rego, S. O. 2003. Tax-avoidance activities of US multinational corporations. Contemporary Accounting Research, 20(4): 805-833.

Rennie, M. W. 1993. Born global. The McKinsey Quarterly(4): 45-53.

Rugman, A., Verbeke, A., \& Yuan, W. 2011. Re-conceptualizing Bartlett and Ghoshal's Classification of National Subsidiary Roles in the Multinational Enterprise. Journal of Management Studies, 48(2): 253-277.

Rugman, A. M. 1981. Inside the multinationals: The economics of internal markets. London: Croom Helm.

Sethi, D. 2009. Are multinational enterprises from the emerging economies global or regional? European Management Journal, 27(5): 356-365.

Shapiro, A. C. 2006. Multinational financial management. Hoboken, NJ: John Wiley \& Sons. 
Srivastava, S. 2003. What is the true level of FDI flows to India? Economic and Political Weekly: 608-610.

Stets, J. E., \& Burke, P. J. 2000. Identity theory and social identity theory. Social psychology quarterly: 224-237.

Tajfel, H., \& Turner, J. C. 2004. The Social Identity Theory of Intergroup Behavior. In J. T. Jost, \& J. Sidanius (Eds.), Political psychology: Key readings: 276-293. New York, NY, US: Psychology Press.

Thite, M., Wilkinson, A., Budhwar, P., \& Mathews, J. A. 2015. Internationalization of emerging Indian multinationals: Linkage, leverage and learning (LLL) perspective. International Business Review.

UNCTAD. 2015. Global Value-Chains: Investment and Trade for Development, World Investment Report. New York and Geneva: United Nation.

Williamson, O. E. 1981. The economics of organization: The transaction cost approach. American Journal of Sociology: 548-577.

Witt, M. A., \& Lewin, A. Y. 2007. Outward foreign direct investment as escape response to home country institutional constraints. Journal of International Business Studies, 38(2): 579-594.

Xiao, G. 2004. People’s Republic of China’s Round-Tripping: FDI: Scale, Causes and Implications.

Zee, H. H., Stotsky, J. G., \& Ley, E. 2002. Tax incentives for business investment: A primer for policy makers in developing countries. World Development, 30(9): 1497-1516.

Zeng, J., \& Glaister, K.W. 2016. Competitive dynamics between multinational enterprises and local internet platform companies in the virtual market in China. British Journal of Management, 27(3): 479-496. 